\title{
COMPARATIVE STUDY OF THE SEISMOSENSORY SYSTEM OF TWO AMUR GRAYLING SPECIES IN THE ZONE OF THE SYMPATRY
}

\author{
Pavel B. MIKHEEV ${ }^{1 *}$, Mikhail A. BAKLANOV², Andrey I. NIKIFOROV², \\ and Alexander A. SEMENCHENKO ${ }^{4}$ \\ ${ }^{1}$ Khabarovsk branch of the Federal State Budget Scientific Institution "Russian Federal Research Institute \\ of Fisheries and Oceanography", Khabarovsk, Russia \\ ${ }^{2}$ Perm State University, Perm, Russia; \\ ${ }^{3}$ Moscow State Institute (University) of International Relations, Ministry of Foreign Affairs \\ of the Russian Federation, Moscow, Russia \\ ${ }^{4}$ Laboratory of Ecology and Evolutionary Biology of Aquatic Organisms, School of Natural Sciences, \\ Far Eastern Federal University, Vladivostok, Russia
}

Mikheev P.B., Baklanov M.A., Nikiforov A.I., Semenchenko A.A. 2019. Comparative study of the seismosensory
system of two Amur grayling species in the zone of the sympatry. Acta Ichthyol. Piscat. 49 (4): 381-388.

Background. This study was initiated for the morphological comparison of two species of recently described Amur graylings collected in the unique zone of their sympatry. This provided an infrequent opportunity for the estimation of the species-specific morphological diversification not determined by environmental conditions dissimilarity. This study aimed to compare the seismosensory systems of two species of Amur grayling, the lower Amur grayling, Thymallus tugarinae Knizhin, Antonov, Safronov et Weiss, 2007, and yellow-spotted grayling, Thymallus flavomaculatus Knizhin, Antonov et Weiss, 2006, collected in sympatric habitats with the inclusion of the published data on other northeast Asia grayling species.

Materials and methods. The comparative study was based on samples of T. tugarinae and T. flavomaculatus specimens collected at species sympatric habitats in the middle stretch of the Anyuy River, one of the biggest tributaries of the Amur River. The lateral line system was stained, the topology was examined, and seismosensory system canal pores were counted. Differences in canal pore numbers between examined species were estimated with Wilcoxon signed-rank test. Also, cluster analysis was carried out.

Results. Examined sympatric species were found to differ in the number of pores and secondary canaliculi topology but were similar to geographically distant grayling species.

Conclusions. The results revealed sympatric morphological divergence of studied species and demonstrated parallelism of interspecies variability of examined features which are likely determined by conditions of species ecological optima. Comparative morphological analysis of the species and forms with questionable taxonomic status should be carried out using material that is collected in different parts of the habitation areal, paying special attention to the sympatry zones, if there are any such cohabitation regions, because the environmental factors have similar effects on all of the analysed species within such zones.

Keywords: Amur River, seismosensory lateral line system, sympatric zone, Thymallus tugarinae, Thymallus flavomaculatus

\section{INTRODUCTION}

Elements of the fish lateral line system are frequently used in identification of systematic and phylogenetic relations of fish taxonomic groups (Jakubowski 1963, Nelson 1972, Neelov 1979, Rassadnikov and Romanov 1985, Čerešnev 1991, Di Dario 2004, Voronina 2009). In this context, analysis of variation in the structure of the grayling lateral line system is of considerable scientific interest.
The habitats of five species of grayling (Thymallidae) from the Amur River basin, differing genetically, morphologically, and ecologically were recently established (Šed'ko 2001, Antonov 2004, Bogutskaya et al. 2008, Ma et al. 2011), and areas of sympatric habitats of some of the species were identified. Geographic variation in lateral line system elements, as represented by clinal modification and ecotopic variability, has been described for the lower Amur 
grayling, Thymallus tugarinae Knizhin, Antonov, Safronov et Weiss, 2007 (see Mikheev 2010); hence species-specific dissimilarities in Amur grayling lateral line features should be investigated in specimens collected in the sympatric habitat zone of these species.

We predicted the differentiation of recently described Amur grayling species by lateral line features according to previously published data on other northeast Asia grayling species (Rassadnikov 1980, Čerešnev et al. 2002). But the level of the morphological differentiation between these close species at the area of their secondary contact (Semenchenko and Atopkin 2012) at the zones of their sympatry is unknown.

This study was initiated for morphological comparison of two species of recently described Amur graylings collected in the unique zone of their sympatry, what is an infrequent opportunity for the estimation of the speciesspecific morphological diversification not determined by environmental conditions dissimilarity. The aim of this study was to compare the lateral line system structure of two Amur grayling species, collected in their sympatric habitat zone with the inclusion of the published data on other northeast Asia grayling species.

\section{MATERIALS AND METHODS}

Fish samples. Fish individuals were collected in June 2009 in the sympatric zone of Thymallus flavomaculatus Knizhin, Antonov et Weiss, 2006 and Thymallus tugarinae $185 \mathrm{~km}$ from the confluence of the Anyuy and Amur rivers $\left(49^{\circ} 12^{\prime} \mathrm{N}, 137^{\circ} 59^{\prime} \mathrm{E}\right)$. The Anyuy River is $393 \mathrm{~km}$ long and enters the Amur River $794 \mathrm{~km}$ from its mouth. The flow rate at the study site reached $2.6 \mathrm{~m} \cdot \mathrm{s}^{-1}$. The stream bed was covered with pebbles and stones on the runs and with cobbles and boulders on the riffles.

Fishes were captured using stationary and drifting gillnets, cast nets, and fly fishing. Specimens were preserved in $4 \%$ formaldehyde prior to processing in the laboratory. Juveniles of similar size and age were investigated to avoid confusion resulting from lateral line system features associated with age and size (Ristovska et al. 2004). Thirty-one T. tugarinae of age $2+, 166.2 \pm 4.1$ $\mathrm{mm}$ fork length $\left(L_{\mathrm{F}}\right)$ and 34 T. flavomaculatus of the same age and $169.1 \pm 2.1 \mathrm{~mm} L_{\mathrm{F}}$ were studied.

Ethics statement. Thymallus flavomaculatus and Thymallus tugarinae are not endangered or protected species in the Russian Federation. They are considered commercial species in the Khabarovsk Territory where the specimens were collected. Limited fishing is permitted in the area. These field studies were in compliance with the limit set by the Federal Agency for Fishery of the Russian Federation*. The sampling area was located beyond the protected territories of the Amur River basin and is not privately owned. The study was approved by the Federal Agency for Fishery of the Russian Federation, which has the highest decision authority concerning fish care and use and can be considered equivalent to the institutional animal care and committees in other countries.

Description of lateral line system. The lateral line system was stained with $1 \%$ methylene blue solution (3,7-Bis (dimethylamino) phenazathionium chloride trihydrate). The terminology for the lateral line system followed previous publications (Disler 1960, Čerešnev 1991, Coombs et al. 2014) (Fig. 1).

All fish were studied by a single operator. Lateral line system topology was examined, and seismosensory system canal pores were counted. Differences in canal pore numbers between examined species were estimated with two-tailed Wilcoxon matched-pairs signed-rank tests, with significance at $P \leq 0.05$. Cluster analyses were applied using the unweighted pair-group method and mean values. Statistica 8.0 software was used.

Observations of the presently reported study were compared with available data on pore numbers in the lateral line system of three grayling species inhabiting northeast Asia: Thymallus arcticus mertensii Valenciennes, 1848; east Siberian grayling, Thymallus arcticus pallasii Valenciennes, 1848; and Alaskan grayling, Thymallus arcticus signifer (Richardson 1823) $^{* *}$ (see Čerešnev et al. 2002).

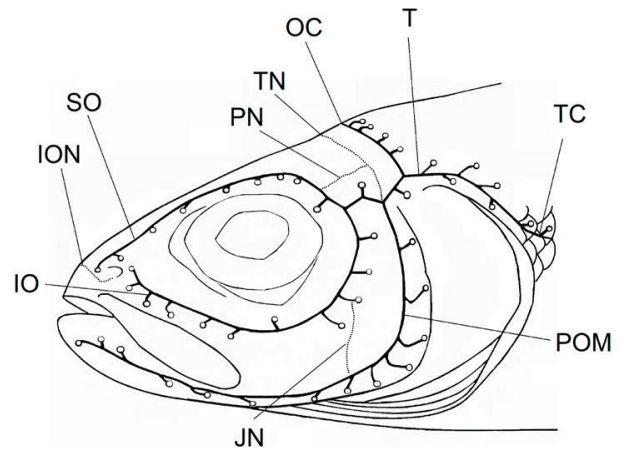

Thymallus tugarinae

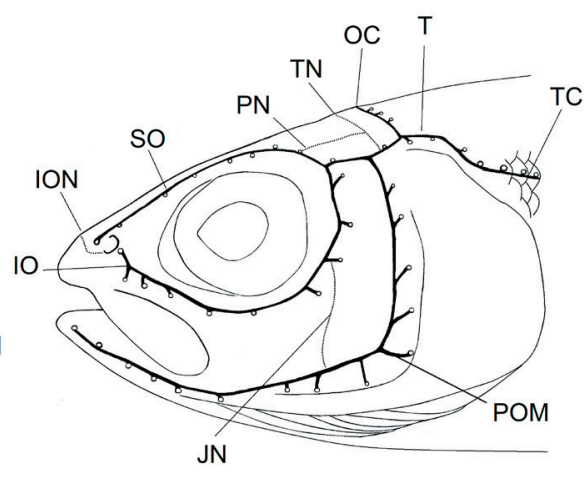

Thymallus flavomaculatus

Fig. 1. Topology of canals, dermal canaliculi, pores, and superficial neuromast dermal grooves in the head seismosensory system of Thymallus tugarinae and Thymallus flavomaculatus; canals: supraorbital (SO), infraorbital (IO), temporal (T), trunk canal (TC), preoperculomandibular (POM), occipital commissure (OC); superficial canal grooves: infraorbital (ION), temporal (TN), parietal (PN), jugal (JN)

\footnotetext{
http://www.consultant.ru/document/cons_doc_LAW_94296/?frame=50\#p4173.

"* According to the Catalog of Fishes and the WoRMS the three subspecies, mentioned in this sentence have now the status of separate species.
} 


\section{RESULTS}

Both superficial canal grooves and enclosed canals were present in the lateral line systems of the studied species. Superficial dermal grooves were located on the head and were categorized as 1) infraorbital, inferior and anterior to the olfactory capsules; 2) temporal, at the temporal area of head; 3) parietal, extending from the supraorbital canal to the area of the temporal dermal grooves; and 4) jugal, in the pre-operculum area. Lines of temporal and parietal dermal grooves were contiguous, others were isolated (Fig. 1).

Enclosed canals were presented as a common system of sensory canals on the head and body. All canals, with the exception of those of the trunk canals, traverse skull bones, which have foramina for canals and the canaliculi extending from them. Canaliculi were open with pores. Supraorbital, postorbital, and suborbital canals joined above and behind the eye on the dermosphenoticum, which has processes extending to each canal, a characteristic of grayling (Rassadnikov 1980, Čerešnev 1991). Left and right postorbital canals are connected by the supratemporal commissure.

Primary canals and superficial dermal grooves topology of the cephalic lateral line system of the studied species showed no differences. Species differed significantly in pore numbers in all canals except left preoperculomandibular (Table 1). Specimens also differed with respect to second-order canaliculus topology in head canals (Fig. 1).

Supraorbital canal. Supraorbital (SO) canal topology was similar in the two examined species. The canal crosses the frontal and nasal bones, with the first two pores perforating the nasal bone, while the remaining are in the frontal bone. The majority of SO canaliculi were directed ventrally. Pores $\mathrm{SO}_{5-7}$ of Thymallus flavomaculatus were directed dorsally in seven specimens, as were $\mathrm{SO}_{6-8}$ in
10 specimens of Thymallus tugarinae. Six specimens of $T$. flavomaculatus exhibited a dorsally oriented final SO pore, in 12 it was centred, and, in the remaining 16, ventrally directed. The final SO pore was ventrally directed in 16 specimens of T. flavomaculatus, and in only 4 did it extend to the orbital rim. This latter pattern occurred in 29 specimens of T. tugarinae, and the canaliculi consistently reached the orbital rim. Supraorbital pore numbers differed in examined species: T. flavomaculatus possessed significantly fewer pores, commonly 8 and never more than 9 (Table 1). Nine specimens of T. tugarinae had 8 pores, 14 had 9, 6 had 10, and one had 11 .

Infraorbital canal. Thymallus flavomaculatus exhibited significantly fewer pores in the infraorbital canal (IO) than did Thymallus tugarinae (Table 1). This was associated with fewer pores in the lacrimal bone of T. flavomaculatus. Lacrimal bones of $21 \mathrm{~T}$. flavomaculatus were perforated with 4 pores, 10 showed 3 perforations, and only 3 had 5 pores. Commonly $4-5$ pores were seen in the lacrimal bone of T. tugarinae. Infraorbital topology also differed with respect to the location of second-order canaliculi. All specimens of T. tugarinae exhibited dorsally-directed IO pores. Twenty $T$. flavomaculatus showed this position, while the remaining 14 had ventrally positioned pores. Postorbital (PO) bones of T. tugarinae showed posteriorly directed pores. This position was typical for $\mathrm{PO}_{2}$ and $\mathrm{PO}_{3}$ of $T$. flavomaculatus. Second-order canaliculi of $\mathrm{PO}_{1}$ were oriented posteriorly in 14 specimens, anteriorly in 2 , and centrally positioned in 18 specimens).

Temporal canal. The temporal canal $(\mathrm{T})$ extends from the dermosphenoticum where the SO and IO are joined to the trunk canal across the pterotic, post-temporal, and supracleithrum bones. Thymallus tugarinae had mean value of six to seven pores in the T, while T. tugarinae had five to six (Table 1). The species also differed in secondorder canaliculi topology (Fig. 1).

Table 1

Lateral line system of Thymallus. tugarinae and Thymallus flavomaculatus from the middle stretch of the Anyuy River, Russia

\begin{tabular}{|c|c|c|c|c|c|}
\hline \multirow{3}{*}{ Canal } & \multicolumn{4}{|c|}{ Pore number } & \multirow{3}{*}{$P$ value } \\
\hline & \multicolumn{2}{|c|}{ Thymallus tugarinae } & \multicolumn{2}{|c|}{ Thymallus flavomaculatus } & \\
\hline & Mean \pm SE & Range & Mean \pm SE & Range & \\
\hline Left SO & $8.9 \pm 0.16$ & $7-11$ & $8.1 \pm 0.10$ & $7-9$ & $<0.01$ \\
\hline Right SO & $8.8 \pm 0.16$ & $7-10$ & $8.1 \pm 0.11$ & $7-9$ & $<0.01$ \\
\hline Left IO & $11.8 \pm 0.18$ & $10-14$ & $10.9 \pm 0.12$ & $10-12$ & $<0.01$ \\
\hline Right IO & $11.6 \pm 0.16$ & $10-13$ & $11.0 \pm 0.10$ & $10-12$ & $<0.01$ \\
\hline Left T & $6.7 \pm 0.13$ & $6-8$ & $5.8 \pm 0.11$ & $5-7$ & $<0.01$ \\
\hline Right $\mathrm{T}$ & $6.7 \pm 0.12$ & $6-8$ & $5.8 \pm 0.10$ & $5-7$ & $<0.01$ \\
\hline Left POM & $13.4 \pm 0.19$ & $11-15$ & $13.6 \pm 0.10$ & $12-14$ & $0.22^{\mathrm{NS}}$ \\
\hline Right POM & $13.1 \pm 0.20$ & $12-15$ & $13.6 \pm 0.14$ & $12-15$ & 0.02 \\
\hline Left TC & $78.9 \pm 0.63$ & $74-83$ & $90.3 \pm 0.54$ & $85-97$ & $<0.01$ \\
\hline Right TC & $79.3 \pm 0.57$ & $73-84$ & $91.0 \pm 0.67$ & $85-98$ & $<0.01$ \\
\hline $\mathrm{OC}$ & $8.4 \pm 0.19$ & $6-11$ & $7.6 \pm 0.16$ & $6-10$ & $<0.01$ \\
\hline
\end{tabular}

$\mathrm{SO}=$ supraorbital, $\mathrm{IO}=$ infraorbital, $\mathrm{T}=$ temporal, $\mathrm{POM}=$ preoperculomandibular, $\mathrm{TC}=$ trunk canal, $\mathrm{OC}=$ occipital commissure, ${ }^{\mathrm{NS}}$ not significant. 
The first $\mathrm{T}$ pore of Thymallus tugarinae was always dorsally-directed and situated between the T origin and its conjunction with the pre-operculomandibular (POM). The first $\mathrm{T}$ pore of $T$. flavomaculatus showed this position in 4 specimens. In 30 specimens, this $\mathrm{T}$ pore was situated at the $\mathrm{SO}, \mathrm{IO}$, and $\mathrm{T}$ joint, and its orientation varied. It was directed dorsally in 11 specimens, diagonally dorsal in 10, ventrally in two specimens or had no canaliculus (11 specimens). $\mathrm{T}_{2}$ of $T$. tugarinae was ventrally-directed and located at the $\mathrm{T}$ and occipital commissure (OC) joint or, in 16 of specimens, anterior to it. The second $\mathrm{T}$ pore of $30 \mathrm{~T}$. flavomaculatus specimens was observed in the same position as the $T_{1}$ pore of T. tugarinae. $\mathrm{T}_{3}$ of $T$. flavomaculatus was positioned on the $\mathrm{T}$ and $\mathrm{POM}$ joint in 10 specimens, on the $\mathrm{T}$ and $\mathrm{OC}$ joint in 18 , and between these joints in six specimens.

Thymallus tugarinae exhibited three to six pores in the $\mathrm{T}$ from the OC joint to the T origin, while Thymallus flavomaculatus had two to four. The orientation of these pores on T. tugarinae varied broadly. The first pore in T. flavomaculatus at this section was always ventrallydirected. The next pore was oriented ventrally, had no canaliculus in three fish, and was posterior in three fish. When two additional pores were present they had no canaliculi. In three specimens, the penultimate pore canaliculus was oriented posteriorly.

Pre-operculomandibular canal. The preoperculomandibular canal continued across the dental, articular, and preopercular bones. Examined species had similar mean value of POM pore numbers. Thirteen to 14 were observed in 21 specimens of lower Amur grayling and in 30 specimens of yellow-spotted grayling. Significant differences were detected for right POM of the studied species.

Distinctions were observed in canaliculus topology in dental bones. In Thymallus tugarinae, the first POM pore is always ventrally-directed. The second, third, and, in $15 \%$ of specimens, fourth pores were dorsally-directed. Other pores in T. tugarinae dental bone are ventrally oriented. In T. flavomaculatus, the first, and subsequent one or two pores, in this bone were always dorsally directed. The next pore had no canaliculus or, in half the specimens, showed a ventral orientation. The next two pores were always ventrally directed.

The remaining anatomical areas examined showed similar canaliculi orientation and pore numbers in the species. The articular bone has no pores in Thymallus tugarinae and Thymallus flavomaculatus, which is also a characteristic of Kamchatka grayling, Thymallus arcticus mertensii (see Rassadnikov 1980) and Alaskan grayling Thymallus arcticus signifer (see Norden 1961). The pre-operculum contains six to eight pores (up to nine in T. flavomaculatus), the first two to four of which are ventrally directed $\left(\mathrm{POM}_{6-9}\right)$ with the remaining posteriorly oriented.

Anomalies were observed in Thymallus tugarinae. A single specimen showed a bifurcated POM9 canaliculus, with two pores. Fused $\mathrm{IO}_{8}$ and $\mathrm{POM}_{8}$ pores forming a commissure between the POM and IO canals with no open pores was observed in one specimen. This condition was also present in a single $T$. flavomaculatus.
Occipital commissure. The occipital commissure (OC) connected the left and right temporal canals and pervaded the tabular bone. The Thymallus tugarinae OC contained 8 to 9 pores; Thymallus flavomaculatus OC had 7 to 8 (Table 1). A symmetrical OC was found in 25 of T. tugarinae individuals. Eleven showed a pore middorsally. Half of $T$. flavomaculatus exhibited symmetric pore positions. Two of these specimens possessed an axial pore in the OC. Thirteen had three pores bilaterally. Four specimens had four pores on each side. Pores in other specimens were distributed in the following manner: In 8 specimens 3 left and 4 right pores were observed in the OC, 5 fish had $4 \mathrm{~L}$ and $3 \mathrm{R}, 1$ had $3 \mathrm{~L}$ and $2 \mathrm{R}$, and 1 had $2 \mathrm{~L}$ and 4R. One fish had 4 pores on the left, 6 on the right, and no axial pore. Thymallus tugarinae showed lower variation in OC pore location. Four fish had an extra pore on the left, and five possessed a right extra pore. One fish had 5 pores on the left and 3 on the right. Both species showed only posteriorly-oriented pores.

The trunk canal. The trunk canal is a T extension starting from the supracleithrum bone. Its origin is marked by $\mathrm{TC}_{1-2}$ pores (Fig. 1). Both species possess a complete trunk canal extending through the body midline to the end of the scale covering on the base of the caudal fin. Thymallus flavomaculatus had a significantly higher number of pores than observed in T. tugarinae (Table 1). Thymallus tugarinae possessed 73 to 84 (most commonly 78 to 82 ) TC pores while T. flavomaculatus had 85 to 98 (most commonly 89 to 91 ).

The studied species differed from graylings of northeast Asia in numbers of the pores in lateral line system (Table 2). Thymallus arcticus pallasii has fewer pores than Thymallus tugarinae in all canals except for the T. compared with Thymallus flavomaculatus it possesses fewer pores in the SO, POM, and OC. Thymallus tugarinae had a greater number of pores in the lateral line canals except for POM and T than does $T$. signifer. The latter has higher numbers of pores in all canals except for the $\mathrm{T}$ compared with $T$. flavomaculatus. Thymallus flavomaculatus had fewer pores in the ST and more in the SO and T compared with T. mertensii. This arctic grayling subspecies is most similar to T. tugarinae. The observed differences between them were limited to greater numbers of SO and IO pores in T. tugarinae. T. tugarinae, and $T$. mertensii were separated by pore numbers from T. flavomaculatus, T. pallasii, and $T$. signifer with clustering. The most similar species are not the sympatric Amur graylings but T. flavomaculatus and T. pallasii (Fig. $2)$, whose ranges are geographically distant.

\section{DISCUSSION}

The effectiveness of the fish lateral line system lies in its morphological features, specific adaptations that are determined by abiotic, ethological, and ontogenetic factors (Coombs et al. 1988, Webb 1989, Fujita and Hosoya 2005, Braun and Grande 2008). Polymorphic species lateral line system variability and the estimation of its adaptive variability in a single taxonomic group of fishes is of interest.

For example, the three-spined stickleback, Gasterosteus aculeatus Linnaeus, 1758, with allopatric 
ecological form development shows differentiation in the acoustic lateral line system structure. Its individuals differ considerably both in exterior morphology and neuromast number (Rundle and Schluter 2004) depending on the ecological niche. The pelagic form, with long gill rakers and fewer canal neuromasts, differs from the benthic. Superior lateral line system sensitivity of the benthic form is an adaptation to its habitat in which the acoustic lateral line system takes precedence over vision. The freshwater stream inhabiting $G$. aculeatus possesses greater numbers of neuromasts than does the marine variety (Wark and Peichel 2010). This is also true of endemic New Zealand sleeper gobies of the genus Gobiomorphus (see Michel et al. 2008) and the Californian tidewater goby, Eucyclogobius newberryi (Girard, 1856) (see Ahnelt et al. 2004). Stream-inhabiting fishes differ from lacustrine fishes in possessing a more highly developed superficial neuromast system, as illustrated by the grubfish,
Cheimarrichthys fosteri Haast, 1874, and Parapercis colias (Forster, 1801) (Pinguipedidae). The former is the only freshwater fish of this family that inhabits turbulent streams and feeds on drift organisms. The latter populates a tidal area with slow laminar currents. Increased numbers of superficial neuromasts and a simple unbranched lateral line system are typical of $C$. fosteri. On the contrary, a paucity of superficial neuromasts and strongly furcated canal system are present in blue cod $P$. colias (see Carton and Montgomery 2004). Canal neuromasts are more sensitive because of their mechanical protection which causes their enlargement and have more hair cells than do superficial neuromasts (Montgomery et al. 2003). Pore numbers and form and canal size determine the difference of intra-canal fluid flows and neuromast stimulation in different species under similar environmental conditions (Coombs et al. 1988, Münz 1989, van Netten 1991). Canal walls function as mechanical filters protecting canal

Pore numbers in lateral line systems of graylings from north-east Asia, according to Čerešnev et al. (2002)

\begin{tabular}{|c|c|c|c|c|c|c|}
\hline \multirow{2}{*}{ Canal } & \multicolumn{2}{|c|}{ Thymallus arcticus pallasii } & \multicolumn{2}{|c|}{$\begin{array}{c}\text { Thymallus arcticus } \\
\text { mertensii }\end{array}$} & \multicolumn{2}{|c|}{ Thymallus arcticus signifer } \\
\hline & Mean & Range & Mean & Range & Mean & Range \\
\hline Left SO & 7.8 & $5-9$ & 7.6 & $6-9$ & 8.6 & $7-10$ \\
\hline Right SO & 7.6 & $5-9$ & 7.5 & $5-9$ & 8.5 & $7-10$ \\
\hline Left IO & 11.0 & $10-12$ & 11.0 & $9-13$ & 12.0 & $10-14$ \\
\hline Right IO & 11.0 & $9-13$ & 11.1 & $9-13$ & 12.1 & $10-15$ \\
\hline Left T & 5.8 & $5-7$ & 6.7 & $6-7$ & 6.1 & $5-7$ \\
\hline Right T & 5.8 & $5-7$ & 6.6 & $6-7$ & 6.0 & $5-8$ \\
\hline Left POM & 12.9 & $11-14$ & 13.5 & $12-16$ & 14.9 & $13-16$ \\
\hline Right POM & 12.6 & $11-14$ & 13.5 & $11-16$ & 15.0 & $12-17$ \\
\hline Left TC & $87.4-91.5$ & $76-103$ & $75.3-84.7$ & 69-94 & $85.5-90.4$ & $77-98$ \\
\hline $\mathrm{OC}$ & 6.5 & $5-9$ & 7.9 & $6-9$ & 8.4 & $7-10$ \\
\hline
\end{tabular}

$\mathrm{SO}=$ supraorbital, $\mathrm{IO}=$ infraorbital, $\mathrm{T}=$ temporal, $\mathrm{POM}=$ preoperculomandibular, $\mathrm{TC}=$ trunk canal, $\mathrm{OC}=$ occipital commissure.

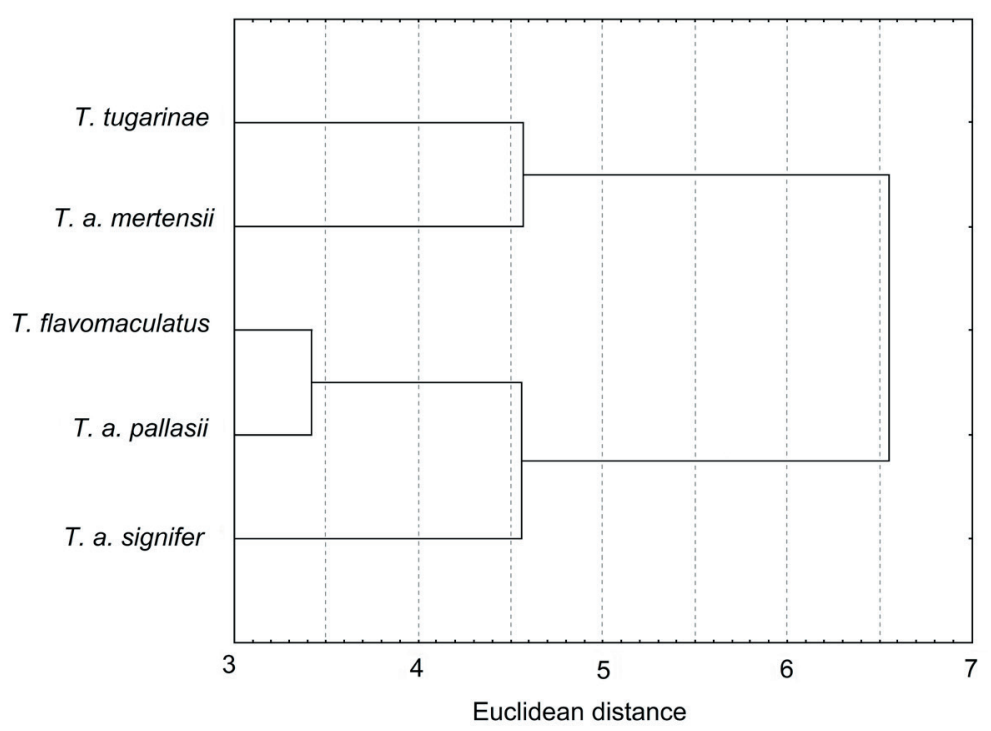

Fig. 2. A dendrogram of graylings divergence based on differences in number of lateral line system pores in selected species of grayling 
neuromasts from direct water flow (Denton and Gray 1983). As a result, they react to oscillation sources in both still water and that with turbulent flow noise (Engelmann et al. 2000, Coombs et al. 2001). Fewer branched canals can be an adaptation that lowers flow noise and increases water vibration sensitivity under turbulent conditions.

The lateral line system structure differentiation of the graylings studied is analogous to that of species inhabiting both rapid and slow-moving streams. Graylings are polymorphic and ecologically plastic fishes (Zinov'ev 2005) inhabiting areas ranging from placid lakes to mountain streams with high flow rate and turbulence. Considering the equivalence of environmental conditions at the zone of sympatric habitation, the most likely explanation for observed differences between Thymallus tugarinae and Thymallus flavomaculatus is the species-specific difference related with conditions of their ecological optimum. Also, the number and location of canal pores could be considered as species-specific, following by their identity at the centre and outer limits of species distribution (Mikheev 2010).

The optimal environmental zone of Thymallus flavomaculatus exists upstream of the large Lower Amur tributaries. Conditions here include the mean flow rate of $0.6-1.0 \mathrm{~m} \mathrm{~s}^{-1}$, mean surface slope $3.5 \%{ }_{0}-6.5 \%$, little alluvial development, mainly unforked courses, and prevailing riffles with definite borders of geomorphological stream forms. The stream bed is covered primarily with rocks and pebbles or blocks and boulders.

On the contrary, Thymallus tugarinae is common in the river lower courses as well as piedmont streams where wintering, feeding, and spawning grounds are present. These courses are generally branched and have alluvial formations. Flat waters prevail, riffles are short and the stream has indefinite bottom relief. The bed is pebbled or pebbled with sands. Flow rate of $0.4-0.7 \mathrm{~m} \cdot \mathrm{s}^{-1}$ and surface mean slope of $2.5 \%-4.5 \%$ are optimal.

A point at which cephalic pore numbers increase when the flow rate of the ecologically optimal zone slows is reported for other graylings of northeast Asia (Čerešnev et al. 2002). Maximum pore numbers are typical for the majority cephalic canals of $T$. signifer, which inhabits lakes. This is reported not only for Asian populations but those in its primary range in North America. The ecological optimal zone of T. mertensii is large deep lakes and slow streams. Its pore numbers in canals of the cephalic lateral line system fall between those of $T$. signifer and T. pallasii.

Thymallus arcticus mertensii and Thymallus tugarinae are closest in ecological preference, and this is likely the reason that they form a cluster (Fig. 2). Rivers with 5\%o$10 \%$ shed slope are optimal for T. pallasii (see Čerešnev et al. 2002). Most likely its high rheophilic habit is the cause of the minimal pore numbers in the cephalic canals (Table 2). Ecological affinity of T. pallasii and T. flavomaculatus is the most probable source of their convergence (Fig. 2).

The differences in lateral line pore numbers found in the presently reported study do not conform to a habitatdetermined hypothesis. Thymallus flavomaculatus and T. pallasii possess the highest numbers of lateral line pores, while T. tugarinae and T. mertensii exhibit the fewest. Thus, unlike cephalic canals, the trunk canal of studied graylings shows a number of pores at variance with their ecological situation. Thymallus signifer, despite its limnophilic features, has a higher mean number of perforated scales than does T. tugarinae. This value in T. signifer is similar to that seen in T. flavomaculatus and T. pallasii (Table 2, Fig. 2), but, according to our hypothesis, their ecological preferences should result in greater differences. It should be pointed out that $T$. signifer inhabits only a small area in Asia east of the Chukotka Peninsula (Čerešnev et al. 2002). As habitat conditions in peripheral populations largely differ from the ecological optimum, it is to be expected that Asian fish exhibit phenomic deviations from the North American populations. However, the mean value of trunk canal pore numbers in the $T$. signifer population from Chukotka (Čerešnev et al. 2002) is similar to that found in specimens from its main habitat (77.4-96.5) (McCart and Pepper 1971). Mean trunk canal pore numbers for North American grayling are $87.15 \pm 0.54$, similar to Chukotka population reported by Čerešnev et al. (2002) (Table 2).

Scale covering develops late, unlike trunk canal system canals (Ristovska et al. 2004). At higher temperatures, development is accelerated and fewer scales are formed, while the inverse is true at low temperatures. It has been shown that fish thyroid status regulating scale numbers is tied to heterochronisms, which are time shifts in scale formation (Levin 2011). If growth is accelerated, scale formation begins earlier with a shorter body, whereas, when growth is decelerated, scale formation starts later and with a longer body (Seymour 1959, Pavlov 2007). Thus, thermal conditions during T. signifer ontogenesis is the most probable explanation for lateral line scale counts observed in this study. Thymallus flavomaculatus develops at a lower temperature than does T. tugarinae. The mean water temperature in the Upper Anyuy River at the T. flavomaculatus post-spawning period was $3^{\circ} \mathrm{C}$ lower than in the lower stream inhabited by T. tugarinae. We suggest the lower temperature during ontogeny of T. signifer, the rheophilic T. flavomaculatus, and T. pallasii as the reason for the higher number of trunk canal pores.

The results of the presently reported study showed that Thymallus tugarinae and Thymallus flavomaculatus specimens collected in their sympatric zone differed by pore numbers in lateral line system canals and the topology of canaliculi. Thymallus tugarinae has greater numbers of pores in all cephalic canals except preoperculomandibular and trunk canal.

Comparisons and successive clustering of examined specimens with graylings of northeast Asia based on canal pore numbers showed Thymallus tugarinae to be similar to Thymallus arcticus mertensii, while Thymallus flavomaculatus is closer to Thymallus arcticus pallasii and Thymallus arcticus signifer. Thymallus pallasii and T. flavomaculatus were the most similar species examined. The difference in the sensory canals pore numbers of studied species demonstrate parallelism of interspecies variability of examined features and likely determined by conditions of species ecological optima. Presumed 
environmental effect on the formation of a number of pores in the seismosensory canals of different species of grayling require further investigations.

Our conclusions have limitations what leaves the space for future research. This study was based on comparative analysis of individuals of two grayling species with specific age and linear size. There are no published data on relations of studied features on the one hand and size and age on the other (except the number of the pores in trunk canal) for considered species of grayling. Possibly, comparison of other age or size groups of individuals of analysed species will be able to reveal a different result. More detailed understanding of the intraspecific ontogenetic variation of examined features required.

\section{ACKNOWLEDGMENTS}

We are grateful to Mr German V. Novomodny for help in organising expeditions, to Mr Roman A. Ershov and $\mathrm{Mr}$ Alexey $\mathrm{K}$. Kyalundzyuga for help in collecting the material for the study, and Mrs Ekaterina P. Kurilova for support in writing. This research did not receive any specific grant from funding agencies in the public, commercial, or not-for-profit sectors.

\section{REFERENCES}

Ahnelt H., Göschl J., Dawson M.N., Jacobs D.K. 2004. Geographical variation in the cephalic lateral line canals of Eucyclogobius newberryi (Teleostei, Gobiidae) and its comparison with molecular phylogeography. Folia Zoologica 53 (4): 358-398.

Antonov A.L. 2004. Novyj vid hariusa Thymallus burejensis sp. nova (Thymallidae) iz bassejna Amura. [A new species of grayling Thymallus burejensis sp. nova (Thymallidae) from the Amur Basin.] Voprosy Ihtiologii 44 (4): 441-451 [In Russian.]

Bogutskaya N.G., Naseka A.M., Shedko S.V., Vasil'eva E.D., Chereshnev I.A. 2008. The fishes of the Amur River: Updated check-list and zoogeography. Ichthyological Exploration of Freshwaters 19 (4): 301-366.

Braun C.B., Grande T. 2008. [4] Evolution of peripheral mechanics for the enhancement of sound reception. Pp. 99-144. DOI: 10.1007/978-0-387-73029-5_4 In: Webb J.F., Fay R.R., Popper A.N. (eds.) Fish bioacoustics, Springer.

Carton A.G., Montgomery J.C. 2004. A comparison of lateral line morphology of blue cod and torrentfish: Two sandperches of the family Pinguipedidae. Environmental Biology of Fishes 70 (2): 123-131. DOI: 10.1023/B:EBFI.0000029340.57735.f8

Čerešnev [Chereshnev] I.A. 1991. Osobennosti topografii sejsmosensornoj sistemy lososevidnyh i svâzi s taksonomičeskim rangom sigovyh ryb. [Specific features of topography of the seismosensory system of Salmoniformes in relation to the taxonomic rank of coregonids.] Pp. 102-111. In: Rešetnikov Û.S. [Reshetnikov Yu.S.], Čerešnev [Chereshnev] I.A. (eds.) Biologičeskie problemy Severa. Sovremennye problemy sigovyh ryb. [Biological problems of the
North. Modern problems of coregonids, Part 1.] DVO AN USSR, Vladivostok, USSR. [In Russian.]

Čerešnev [Chereshnev] I.A., Volobuev V.V., Šestakiv [Shestakiv] A.V., Frolov S.V. 2002. Lososevidnye ryby Severo-Vostoka Rossii. [Salmonoid fishes in Russian North-East.] Dalnauka, Vladivostok, Russia. [In Russian.]

Coombs S., Braun C.B., Donovan B. 2001. The orienting response of Lake Michigan mottled sculpin is mediated by canal neuromasts. Journal of Experimental Biology 204 (2): 337-348.

Coombs S., Janssen J., Webb J.F. 1988. [Chapter 22] Diversity of lateral line systems: Evolutionary and functional considerations. Pp. 553-593. DOI: 10.1007/978-1-4612-3714-3 22 In: Atema J., Fay R.R., Popper A.N., Tavolga W.N. (eds.) Sensory biology of aquatic animals. Springer-Verlag, New York, Belin, Heidelberg, London, Paris, Tokyo.

Coombs S.C., Bleckmann H., Fay R.R., Popper A.N. (eds.) 2014. The lateral line system. Springer, New York, Heidelberg, Dordrecht, London. DOI: 10.1007/978-1-4614-8851-4

Denton E.J., Gray J.A.B. 1983. Mechanical factors in the excitation of clupeid lateral lines. Proceedings of the Royal Society B Biological Sciences 218 (1210): 1-26. DOI: 10.1098/rspb.1983.0023

Di Dario F. 2004. Homology between the recessus lateralis and cephalic sensory canals, with the proposition of additional synapomorphies for the Clupeiformes and the Clupeoidei. Zoological Journal of the Linnean Society 141 (2): 257-270. DOI: 10.1111/j.10963642.2004.00122.x

Disler N.N. 1960. Organy čuvstv sistemy bokovoj linii i ih značenie $\mathrm{v}$ povedenii ryb. [Lateral line sense organs and their importance in fish behaviour.] Izdatel'stvo AN SSSR, Moskva, USSR. [In Russian.]

Engelmann J., Hanke W., Mogdans J., Bleckmann H. 2000. Hydrodynamic stimuli and the fish lateral line. Nature 408 (6808): 51-52. DOI: 10.1038/35040706

Fujita T., Hosoya K. 2005. Cephalic lateral line systems in the Far Eastern species of the genus Phoxinus (Cyprinidae). Ichthyological Research 52 (4): 336342. DOI: 10.1007/s10228-005-0290-6

Jakubowski M. 1963. Cutaneous sense organs of fishes. I. The lateral-line organs in the stone-perch (Acerina cernua L.). Acta Biologica Cracoviensia Series Zoologia 6: 59-78.

Levin B.A. 2011. Ontogenetic causes and mechanisms for formation of differences in number of fish scales. Russian Journal of Developmental Biology 42 (3): 186-191. DOI: 10.1134/S1062360411030106

Ma B., Sun J., Jiang Z. 2011. [Taxonomic status of three fish species in Thymallus from upper Heilongjiang River based on mitochondrial control region sequence variation.] Journal of Fishery Sciences of China 18 (2): 314-321. DOI: 10.3724/SP.J.1118.2011.00314 [In Chinese with English abstract.]

McCart P., Pepper V.A. 1971. Geographic variation in the lateral line scale counts of the arctic grayling, 
Thymallus arcticus. Journal of the Fisheries Research Board of Canada 28 (5): 749-754. DOI: 10.1139/f71103

Michel B., Hicks B.J., Stölting K.N., Clarke A.C., Stevens M.I., Tana R., Meyer A., van den Heuvel M.R. 2008. Distinct migratory and non-migratory ecotypes of an endemic New Zealand eleotrid (Gobiomorphus cotidianus)-Implications for incipient speciation in island freshwater fish species. BMC Evolutionary Biology 8 (49): 1-14. DOI: 10.1186/1471-2148-8-49

Mikheev P.B. 2010. Seismosensory system of the lower Amur grayling Thymallus tugarinae (Thymallidae) from the Anyuy River. Journal of Ichthyology 50 (9): 745-749. DOI: 10.1134/S0032945210090067

Montgomery J.C., McDonald F., Baker C.F., Carton A.G., Ling N. 2003. Sensory integration in the hydrodynamic world of rainbow trout. Proceedings of the Royal Society of London Series B - Biological Sciences 270 (Suppl.): S195-S197.

Münz H. 1989. [14] Functional organization of the lateral line periphery. Pp. 285-297. DOI: 10.1007/978-14612-3560-6_14 In: Coombs S., Görner P., Münz H. (eds.) The mechanosensory lateral line. SpringerVerlag, New York, Berlin, Heidelberg, London, Paris, Tokyo.

Neelov A.V. 1979. Sejsmosensornaâ sistema i klassifikaciâ kerčakovyh ryb (Cottidae, Myoxocephalinae, Artediellinae). [Seismosensory system and the classification of sculpins Cottidae, Myoxocephalinae, Artediellinae.] Izdatel'stvo Nauka, Leningrad, USSR. [In Russian.]

Nelson G.J. 1972. Cephalic sensory canals, pitlines and the classification of esocoid fishes, with notes on galaxiid and other teleosts. American Museum Novitates No. 2492: 1-49.

Norden C.R. 1961. Comparative osteology of representative salmonid fishes, with particular reference to the grayling (Thymallus arcticus) and its phylogeny. Journal of the Fisheries Research Board of Canada 18 (5): 679-791. DOI: 10.1139/f61-052

Pavlov D.A. 2007. Morfologičeskaâ izmenčivost' v rannem ontogeneze kostistyh ryb. [Morphological variability in early bony fish ontogeny.] GEOS, Moskva, Russia. [In Russian.]

Rassadnikov O.A. 1980. Morfologiâ sejsmosensornoj sistemy nekotoryh lososevyh. [Morphology of some salmonid fishes seismosensory system.] Pp. 104-112. In: Konovalov S.M. (ed.) Populâcionnaâ biologiâ i sistematika lososevyh. [Population biology and systematics of salmonids.] DVNC AN SSSR [Far Eastern Scientific Centre, Academy of Sciences of the USSR.], Vladivostok, USSR. [In Russian.]

Rassadnikov O.A., Romanov N.S. 1985. Sejsmosensornaâ sistema nekotoryh lososevidnyh ryb. [Seismosensory system of certain salmonid fishes.] Pp. 154-168. In: Konovalov S.M. (ed.) Biologičeskie issledovaniâ lososevyh. [Biological research of salmonids.] DVNC
AN SSSR [Far Eastern Scientific Centre, Academy of Sciences of the USSR.], Vladivostok, USSR. [In Russian.]

Ristovska M., Karaman B., Verraes W., Adriaens D. 2004. Development of the cranial lateral-line system and canal related bones in Salmo letnica Kar. (Teleostei: Salmonidae). Pp. 1-7. In: Proceedings of the Congress of the Balkan Water Observation and Information System for Decision Support, 25-29 May 2004, Ohrid, Republic of Macedonia.

Rundle H.D., Schluter D. 2004. [9] Natural selection and ecological speciation in sticklebacks. Pp. 192209. DOI: 10.1017/CBO9781139342179.011 In: Dieckmann U., Doebeli M., Metz J.A.J, Tautz D. (eds.) Adaptive speciation. Cambridge University Press, Cambridge, UK. DOI: 10.1017/CBO9781139342179

Semenchenko A.A., Atopkin D.M. 2012. A comparative analysis of the Far Eastern grayling species Thymallus tugarinae and Thymallus grubii flavomaculatus based on the data from mitochondrial DNA cytochrome $b$ gene sequencing. Journal of Marine Biology 38 (7): 520-528. DOI: 10.1134/S1063074012070024

Seymour A. 1959. Effects of temperature upon the formation of vertebrae and fin rays in young chinook salmon. Transactions of the American Fisheries Society 88 (1): 58-69. DOI: 10.1577/1548-8659(1959)88[58:EOTUTF]2.0.CO;2

Šed'ko [Shedko] S.V. 2001. Spisok kruglorotyh i ryb presnyh vod poberež'â Primor'â. [List of cyclostomes and fishes of fresh waters of the coast of Primorie.] Pp. 229-249. In: Makarčenko E.A. (ed.) Čteniâ pamâti V.Â. Levanidova. [Vladimir Ya. Levanidov Biennial Memorial Meetings.] Vol. 1, Izdatel'stvo Dal'nauka, Vladivostok, Russia. [In Russian.]

van Netten S.M. 1991. Hydrodynamics of the excitation of the cupula in the fish canal lateral line. Journal of the Acoustical Society of America 89 (1): 310-319. DOI: $10.1121 / 1.400512$

Voronina E.P. 2009. Specific features of the seismosensory system and their use in the systematics of five families of the order Pleuronectiformes. Journal of Ichthyology 49 (5): 349-361. DOI: 10.1134/S0032945209050014

Wark A.R., Peichel C.L. 2010. Lateral line diversity among ecologically divergent threespine stickleback populations. Journal of Experimental Biology 213 (1): 108-117. DOI: 10.1242/jeb.031625

Webb J.F. 1989. Gross morphology and evolution of the mechanoreceptive lateral-line system in teleost fishes (Part 1 of 2). Brain, Behavior and Evolution 33 (1): 34-53. DOI: 10.1159/000115896

Zinov'ev E.A. 2005. Èkologiâ i sistematika hariusovyh ryb Evrazii. [Ecology and systematics of grayling fishes of Eurasia.] Permskij gosudarstvennyj universitet. [Perm State University], Perm, Russia. [In Russian.]

Received: 5 July 2018

Accepted: 31 July 2019

Published electronically: 15 December 2019 